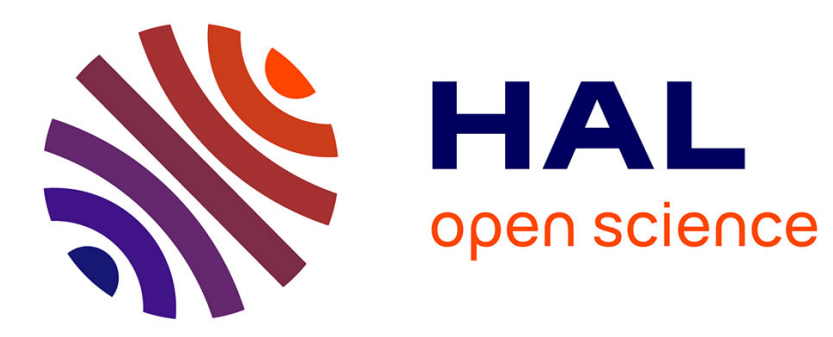

\title{
Thermal testing and numerical simulation of a prototype cell using light wallboards coupling Vacuum Isolation Panels and Phase Change Material
}

\author{
Maha Ahmad, André Bontemps, Hébert Sallée, Daniel Quénard
}

\section{- To cite this version:}

Maha Ahmad, André Bontemps, Hébert Sallée, Daniel Quénard. Thermal testing and numerical simulation of a prototype cell using light wallboards coupling Vacuum Isolation Panels and Phase Change Material. Energy and Buildings, 2006, 38 (6), pp.673-681. 10.1016/j.enbuild.2005.11.002 . hal-00184237

\section{HAL Id: hal-00184237 \\ https://hal.science/hal-00184237}

Submitted on 11 Feb 2020

HAL is a multi-disciplinary open access archive for the deposit and dissemination of scientific research documents, whether they are published or not. The documents may come from teaching and research institutions in France or abroad, or from public or private research centers.
L'archive ouverte pluridisciplinaire HAL, est destinée au dépôt et à la diffusion de documents scientifiques de niveau recherche, publiés ou non, émanant des établissements d'enseignement et de recherche français ou étrangers, des laboratoires publics ou privés. 


\title{
Thermal testing and numerical simulation of a prototype cell using light wallboards coupling vacuum isolation panels and phase change material
}

\author{
Maha Ahmad ${ }^{\mathrm{a}, *}$, André Bontemps ${ }^{\mathrm{b}}$, Hébert Sallée ${ }^{\mathrm{a}}$, Daniel Quenard ${ }^{\mathrm{a}}$ \\ ${ }^{a}$ Centre Scientifique et Technique du Bâtiment, CSTB, 24, rue Joseph Fourier, Saint Martin d'Hères, France \\ ${ }^{\mathrm{b}}$ Université Joseph Fourier, LEGI/GRETh, 17, Avenue des Martyrs, 38054 Grenoble Cedex, France
}

\begin{abstract}
Light envelopes are more and more frequently used in modern buildings but they do not present sufficient thermal inertia. A solution to increase this inertia is to incorporate a phase change material (PCM) in this envelope. This paper presents the performance of a test-cell with a new structure of light wallboards containing PCMs submitted to climatic variation and a comparison is made with a test-cell without PCMs. To improve the wallboard efficiency a vacuum insulation panel (VIP) was associated to the PCM panel. This new structure allows the apparent heat capacity of the building to be increased, the solar energy transmitted by windows to be stored without raising the indoor cell temperature, and the thickness of the wallboard to be decreased compared with that of traditional wallboards. An experimental study was carried out by measuring temperature and heat fluxes on and through the wallboards. The indoor temperature, which has a special importance for occupants, was also measured.

A numerical simulation with the TRNSYS software was carried out in adding a new module representing the new wallboard. It showed a good agreement with experimental results. This new tool will allow users to simulate the thermal behaviour of buildings having walls with PCMs.
\end{abstract}

Keywords: Latent heat storage; Phase change materials; PCM; Computer simulation; TRNSYS; Test-cell; Vacuum insulation panel; VIP

\section{Introduction}

The building sector has become (together with the industrial sector) the world dominant energy consumer with $28 \%$ of the overall energy consumption [1]. In western countries and in France in particular, this proportion reaches $45 \%$ [2] and most of this consumption comes from heating and air-conditioning systems which ensure thermal comfort of occupants. This comfort depends on the desired physiological state for which people can have the feeling of heat or cold. This comfort feeling is, in part, controlled by heat exchange between the body and the environment. For example, the atmosphere can be felt comfortable when there are few variations of temperature in space, from one place or one room to another, or in time either during the day or from a season to another. Moreover, if the air temperature is an important parameter, the wall temperature has also an influence on the comfort feeling [3].

Thermal comfort can be obtained by passive or active means. The passive means are primarily related to thermal

\footnotetext{
* Corresponding author.

E-mail address: m.ahmad@cstb.fr (M. Ahmad).
}

storage in the structure of buildings. The active means relate to the transfer of the energy, stored or not, with mechanical or thermal systems.

The buildings with a traditional structure have a large thermal inertia (sensible heat storage) and supply natural air conditioning in the rooms. In the commercial sector, the trend is to decrease the wall thickness to reduce the weight and then the transport costs and the construction time. Latent heat storage by incorporating a phase change material (PCM) into some building materials is an attractive way to compensate for the small storage capacity of most existing modern buildings which use light construction as well as of buildings of the next generation.

Reviews of principles, of available PCMs and current or expected applications were made by a significant number of authors and we can cite the publications of Hasnain [4] and Zalba et al. [5]. Concerning the use of PCM in building materials, a methodology for choosing a PCM has been developed by Peippo et al. [6] for passive solar heating and criteria of choice were given by $\mathrm{Gu}$ et al. for thermal energy recovery with air-conditioning systems [7].

After having studied a wall with PCM, several authors studied the performances of these PCM wallboards in cells tests and compared the experimental results with those obtained by 


\section{Nomenclature}

$A_{\mathrm{f}} \quad$ area of frame $\left(\mathrm{m}^{2}\right)$

$A_{\mathrm{g}} \quad$ area of glazed surface $\left(\mathrm{m}^{2}\right)$

$C_{i} \quad$ heat capacity of the $i$ th zone $\left(\mathrm{J} \mathrm{K}^{-1}\right)$

$C_{p} \quad$ specific heat capacity at constant pressure $\left(\mathrm{J} \mathrm{kg}^{-1} \mathrm{~K}^{-1}\right.$ )

$C_{\text {pe }} \quad$ specific equivalent heat capacity at constant pressure $\left(\mathrm{J} \mathrm{kg}^{-1} \mathrm{~K}^{-1}\right)$

$i \quad i$ th node

$L \quad$ latent heat $\left(\mathrm{J} \mathrm{kg}^{-1}\right)$

$\dot{Q} \quad$ heat flow rate (W)

$\dot{Q}_{i} \quad$ sum of the heat flow rates at the $i$ th node (W)

$S \quad$ volume source of heat $\left(\mathrm{W} \mathrm{m}^{-3}\right)$

$t \quad$ time (s)

$T$ temperature $\left(\mathrm{K},{ }^{\circ} \mathrm{C}\right)$

$U \quad$ overall heat transfer coefficient $\left(\mathrm{W} \mathrm{\textrm {m } ^ { 2 }} \mathrm{K}^{-1}\right)$

$x, y, z$ coordinates $(\mathrm{m})$

\section{Greek letters}

$\lambda$ thermal conductivity $\left(\mathrm{W} \mathrm{m}^{-1} \mathrm{~K}^{-1}\right)$

$\lambda_{\mathrm{M}}$ thermal conductivity of the PCM $\left(\mathrm{W} \mathrm{m}^{-1} \mathrm{~K}^{-1}\right)$

$\rho \quad$ density $\left(\mathrm{kg} \mathrm{m}^{-3}\right)$

$\rho_{\mathrm{M}} \quad$ density of the PCM $\left(\mathrm{kg} \mathrm{m}^{-3}\right)$

$\varphi_{\mathrm{e}} \quad$ external flux $\left(\mathrm{W} \mathrm{m}^{2}\right)$

$\varphi_{\mathrm{i}} \quad$ internal flux $\left(\mathrm{W} \mathrm{m}^{2}\right)$

$\begin{array}{ll}\text { Subscripts } \\ \mathrm{i} & \text { inside } \\ i & \text { ith node } \\ \mathrm{L} & \text { liquid } \\ \mathrm{O} & \text { outside } \\ \mathrm{S} & \text { solid }\end{array}$

numerical simulation. Others carried out only numerical simulations on a whole building or on a part of the building. Kondo et al. [8] developed and tested a wall with PCM. They also studied cells test and developed a simulation program to study the possibility of controlling the fluctuations of temperature. Kissock et al. [9] realized tests on low-size cells with walls manufactured by impregnation of a mixture of hydrocarbon alkyl. These authors compared the results obtained on a reference cell and the cell with PCM. They used wallboards impregnated by paraffin based PCMs and analysed numerically and experimentally a mock-up simulating a house. Peippo et al. presented a method to determine the optimal thickness of a wallboard with PCM [6].

Scalat et al. [10] carried out tests on a room having walls and partitions with PCM. They compared their results with those obtained on an adjacent identical room with conventional walls.

Athienitis et al. [11] made an extensive experimental study as well as a numerical simulation on a cell test on scale 1 . The walls had their interior layer made of plasterboard containing approximately $25 \%$ in weight of a PCM (butyl stearate). They showed that the use of the PCM could lead to a reduction of $4{ }^{\circ} \mathrm{C}$ of the indoor temperature.
The house of BASF [12] has a new lining which contains 10$25 \%$ of paraffin particles which can store the latent heat. The wax is incorporated in microcapsules which can be easily incorporated in the concrete and the plaster. The energy consumption per square meter of this house requires only three litres of fuel per annum. This concept also makes it possible to reduce the $\mathrm{CO}_{2}$ emission of $80 \%$.

Development of a light envelope leads to study multi-layer walls which incorporate electro-chromic glazing, aerogel and PCM [13] thus reducing heating, cutting overheating and taking advantage of solar radiation.

All these studies showed a lot of potential for development of wallboards containing PCMs. On the other hand, using a vacuum isolation panel (VIP) in a wallboard is another way to get a light structure so reducing thermal losses and improving efficiency. Coupling a VIP with a PCM structure combines the advantages of the two systems. The objective of the present study is to analyze experimentally and by numerical simulation the thermal behaviour of two test-cells, one with thin wallboards containing a PCM and a VIP, the other with wallboards without PCMs.

This study is a part of a larger project and in a previous work a PCM wallboard was developed in order to define a component for the light envelope of buildings [3]. Amongst the criteria of the wallboard definition, four were considered imperative: (i) a melting temperature of about $23{ }^{\circ} \mathrm{C}$, (ii) a high storage heat capacity, (iii) a small thickness and (iv) the lowest cost. Several wallboard types were tested. The chosen solution was commercial plasterboard in polyvinyl chloride (PVC) filled up with a PCM. Several PCM were tested and the selected end product was the polyethylene glycol 600 (PEG 600) whose properties are given in Table 1 . This choice results from a compromise between the availability, cost and thermal performance. The main problem of this choice remains the large range of the melting temperatures $\left(21-25^{\circ} \mathrm{C}\right)$. However, tests of others PCMs are in progress to improve the melting temperature control and the heat storage capacity.

\section{Design and construction of the cells}

\subsection{Structure}

Each test-cell consists of one glazed face and five opaque faces insulated with VIPs. In order to increase thermal inertia, one of them is equipped with five panels containing a PCM. Fig. 1( $a$ and $b)$ presents the structure of wallboards with and without PCMs. For the cell without PCM, the walls are constituted of a VIP sandwiched between a fibre panel and a plywood panel. For the cell with PCM, walls are constituted of

Table 1

Physical properties of polyethylene glycol (PEG) 600

\begin{tabular}{ll}
\hline Molar mass $\left(\mathrm{g} \mathrm{mol}^{-1}\right)$ & $570-630$ \\
Density at $20{ }^{\circ} \mathrm{C}\left(\mathrm{kg} \mathrm{m}^{-3}\right)$ & 1128 \\
Melting temperature $\left({ }^{\circ} \mathrm{C}\right)$ & $21-25$ \\
Liquid specific heat capacity $\left(\mathrm{J} \mathrm{kg}^{-1} \mathrm{~K}^{-1}\right)$ & 2490 \\
Latent heat of fusion $\left(\mathrm{kJ} \mathrm{kg}^{-1}\right)$ & 148 \\
\hline
\end{tabular}




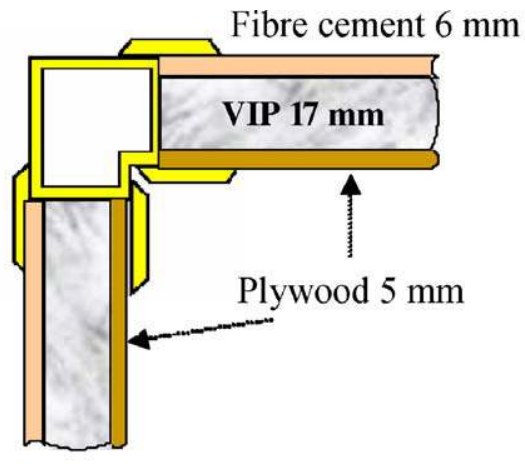

(a)

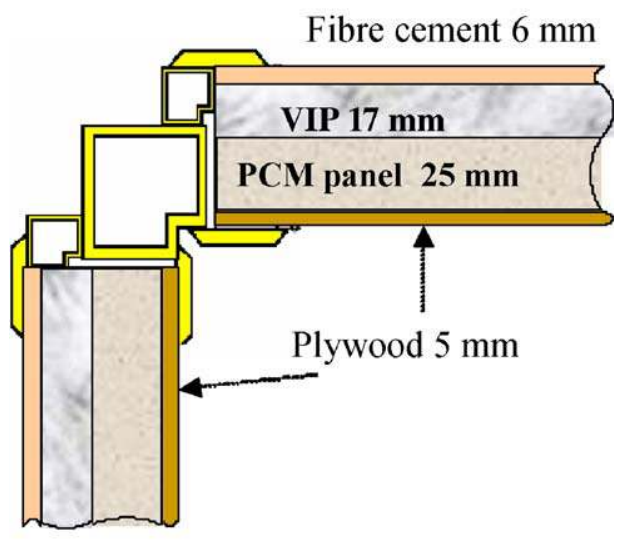

(b)

Fig. 1. Cross-section of the wallboards: (a) for test-cell without PCM and (b) for test-cell with PCM.

a VIP between a fibre panel and a plywood panel, and associated with a panel containing a PCM. Taking into account the results obtained in the first phase with different panels, a $25 \mathrm{~mm}$ thick, PVC alveolar panel was preferred to a polycarbonate one which proved too fragile. Each PVC panel was filled with $20 \mathrm{~kg}$ of PCM (Fig. 2). The chosen thickness corresponds to an available commercial panel and the amount of PCM is slightly greater than that needed.

The walls were placed on a frame made of white PVC profiles, reinforced with steel tubes in order to ensure a good support. White PVC was selected as a material having a good resistance to UV radiations as well as a low absorption coefficient of solar radiation. The both windows were equipped with traditional double glazing of $4 / 16 / 4 \mathrm{~mm}$ leading to a solar

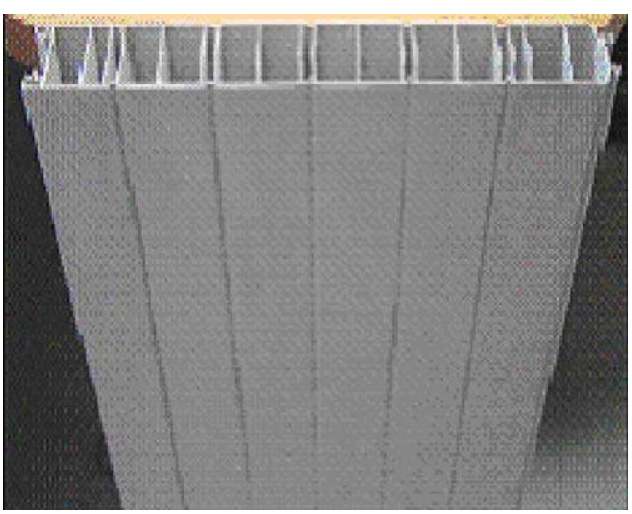

Fig. 2. View of a PVC panel.

radiation absorption coefficient of 0.8 . The dimensions of the panel components are summarized in Table 2 .

\subsection{Orientation}

It was decided that the glass side would be oriented south in order to collect the maximum solar radiation, in particular during winter (Fig. 3). In the chosen design, PCM panels placed inside the cell can store the solar energy entering the glazed face. The VIP panels placed on the exterior side of the walls play their function of thermal insulators, protecting the PCM from external thermal aggressions. Fig. 4 presents a general view of the two test-cells.

\section{Instrumentation and measurements}

\subsection{Sensors}

The test-cells were instrumented using thermocouples and heat flux sensors. The calibration of the sensors has been carried out by the manufacturer and verified at the laboratory before use. These sensors were placed on each face of the walls, in order to measure the heat flux between outside and wall, and between wall and inside. These sensors cover an area of $100 \mathrm{~mm} \times 100 \mathrm{~mm}$ for a thickness of approximately $420 \mu \mathrm{m}$. Their thermal conductivities are much less that those of the VIPs and, in this case, the sensors do not disturb the flux stream lines. Twenty sensors were used for the two cells (10 for each cell). The heat flux sensors deliver a positive or negative tension depending on the direction of heat flow. A thermocouple of T type is integrated into each flux sensor. The sensors are located in the centre of each panel according to the diagram of Fig. 5.

Table 2

Geometrical characteristics of test-cells

\begin{tabular}{|c|c|c|c|c|c|c|}
\hline & \multicolumn{3}{|c|}{ Cell with PCM } & \multicolumn{3}{|c|}{ Cell without PCM } \\
\hline & Width (mm) & Length (mm) & Thickness (mm) & Width (mm) & Length (mm) & Thickness (mm) \\
\hline Plywood & 900 & 900 & 5 & 900 & 900 & 5 \\
\hline Alveolar PVC panel containing the PCM & 920 & 920 & 25 & - & - & - \\
\hline Vacuum insulation panel (VIP) & 900 & 900 & 18 & 900 & 900 & 18 \\
\hline Plate fibre cement & 900 & 900 & 6 & 900 & 900 & 6 \\
\hline
\end{tabular}




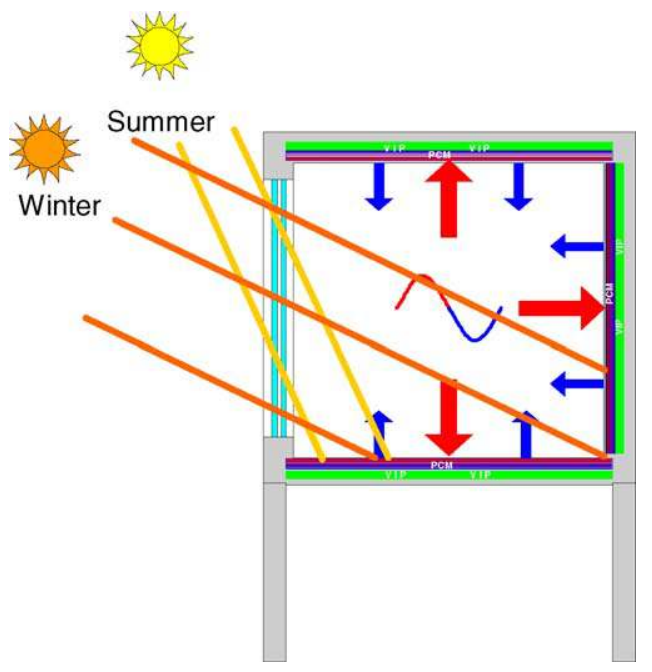

Fig. 3. Principle of solar heating of test-cells.

\subsection{Data acquisition}

Data acquisition is achieved by an autonomous system, placed in sealed box with an electrical alimentation on mains or battery. It acquires the output signals from the heat flux sensors and thermocouples, digitises, treats them and then saves the results. Data are directly collected with help of an interface network between the measurement station and a computer equipped with an application software. The climatic parameters are measured in the meteorological station of the research centre, located nearby $(50 \mathrm{~m})$. This station provides the external temperature, horizontal direct and diffuse solar radiation, wind velocity and specific humidity. These parameters allow us to carry out heat balance and to feed the numerical simulation software.

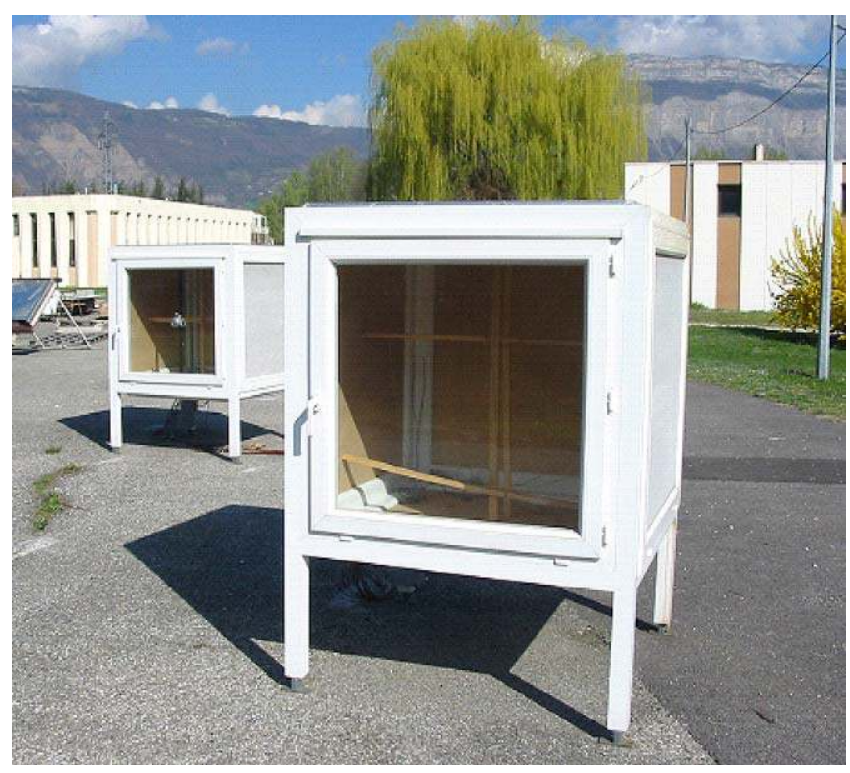

Fig. 4. Exterior view of test-cells.
Fibre cement

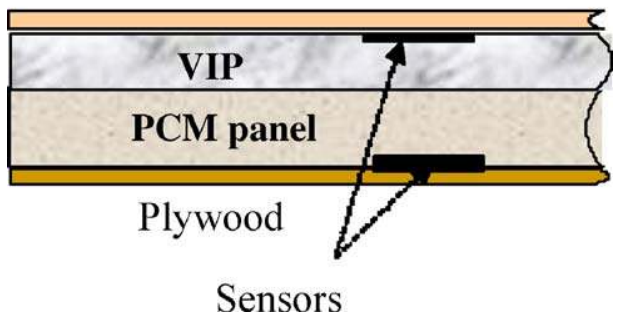

Fig. 5. Location of sensors of flux/temperature on the panels with PCM (same location for the panels without PCM).

\section{Experimental results and discussion}

The simultaneous acquisitions of measurements on the two cells began on 26 August 2003 and are always continuing. To discuss the results, few days were extracted from the data.

\subsection{Temperature evolution}

Fig. 6 presents the evolution of the outdoor and the indoor temperatures of the two test-cells (with and without PCM wallboards). For comparison the total solar flux is also presented. It can be seen that at the hottest period of the day the temperature of the cell without PCM exceeds $60{ }^{\circ} \mathrm{C}$, whereas that of the cell with PCM reaches approximately $40{ }^{\circ} \mathrm{C}$. Conversely, during the night, the temperature of the cell with PCM drops to $23{ }^{\circ} \mathrm{C}$, whereas the other nearly joins the outside temperature of $12{ }^{\circ} \mathrm{C}$. The diurnal/nocturne temperature amplitudes of the two cells with and without PCM are, respectively, 20 and $50{ }^{\circ} \mathrm{C}$. The PCM completely fulfils its function of heat absorber.

\subsection{Flux evolution}

By convention and due to the fluxmeter wiring, heat flow entering the cell is positive (Fig. 7). According to the day time, the heat flux coming from outdoor $\varphi_{\mathrm{e}}$ and the heat flux coming from indoor $\varphi_{\mathrm{i}}$ can be positive or negative. From the solar

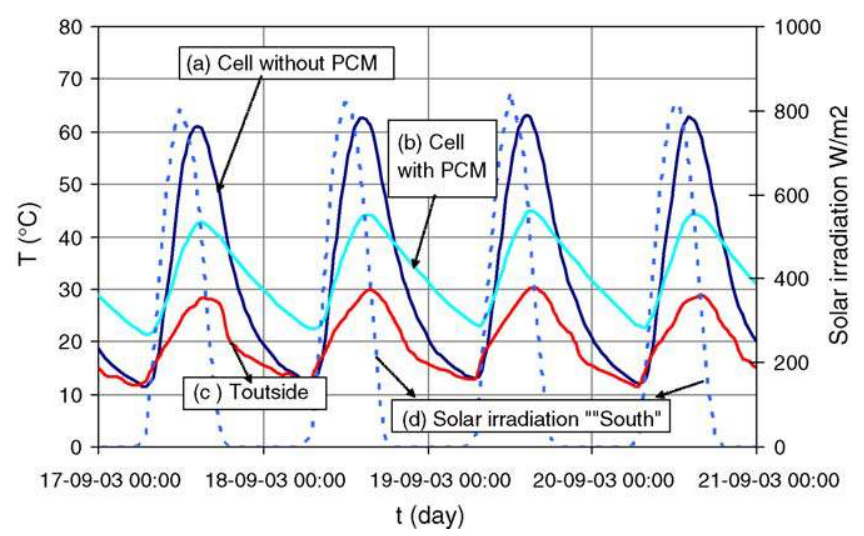

Fig. 6. Thermal behaviour of the two test-cells (without and with PCM): (a) indoor temperature variation of the cell without PCM, (b) indoor temperature variation of the cell with PCM, (c) outdoor temperature variation and (d) solar irradiation (vertical, south orientation). 


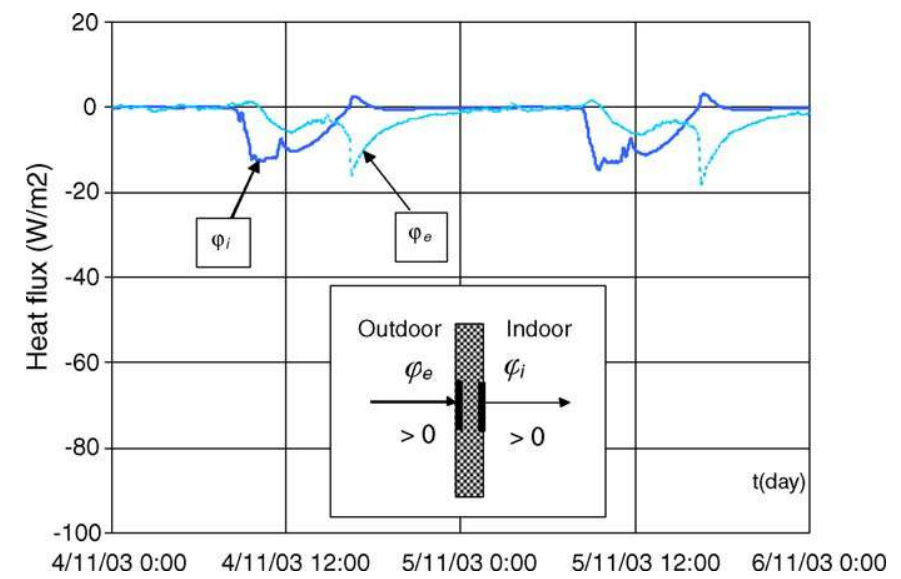

Fig. 7. Test-cell without PCM: heat flux variation, external $\left(\varphi_{\mathrm{e}}\right)$ and internal $\left(\varphi_{\mathrm{i}}\right)$. The positive direction of flux is shown in the inset.

radiation measured on a horizontal plane, the vertical components on each face of the cells are calculated using the software METEONORM. It is a Global Meteorological Database for Solar Energy and Applied Meteorology. It is mainly a method of calculation of the solar radiation on arbitrarily directed surfaces whatever the desired place [14].

\section{Heat flux analysis and discussion}

\subsection{Heat flux analysis on the west panel}

It is noted that heat fluxes on the external surfaces have the same behaviour, except for the north wall and the floor. As a consequence, only results on the western wall are analyzed. In Figs. 8 and 9 are given the variations of the fluxes during 2 consecutive days on the external side $\left(\varphi_{\mathrm{e}}\right)$ and on the internal side $\left(\varphi_{\mathrm{i}}\right)$ of the walls without and with PCM, respectively. Fluxes have a higher amplitude in the case of the cells with PCM. The heat storage and release of the walls without PCM are very weak compared to those containing of the PCM. In Fig. 9 is also presented the solar fluxes on the southern face (glazing) which corresponds to the power which, through the

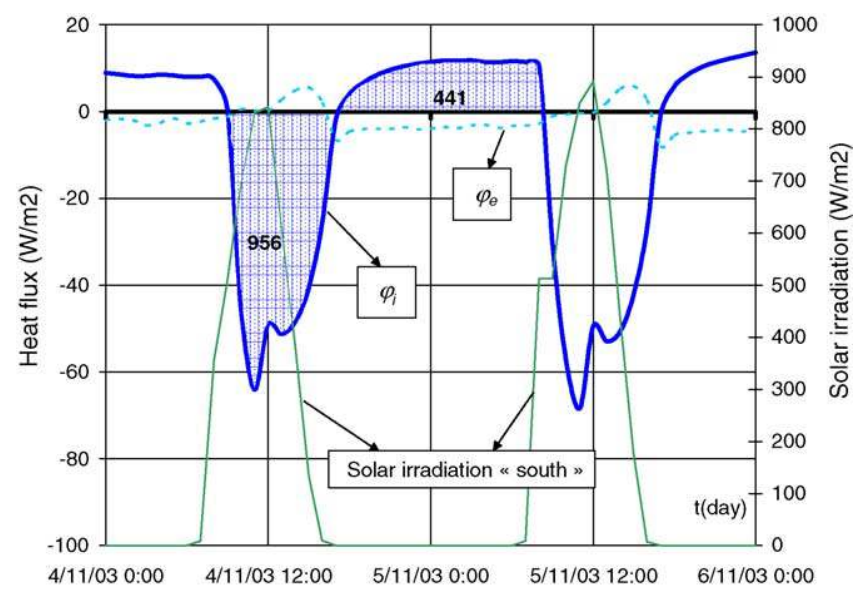

Fig. 8. Test-cell with PCM: heat flux variation, external $\left(\varphi_{\mathrm{e}}\right)$ and internal $\left(\varphi_{\mathrm{i}}\right)$.

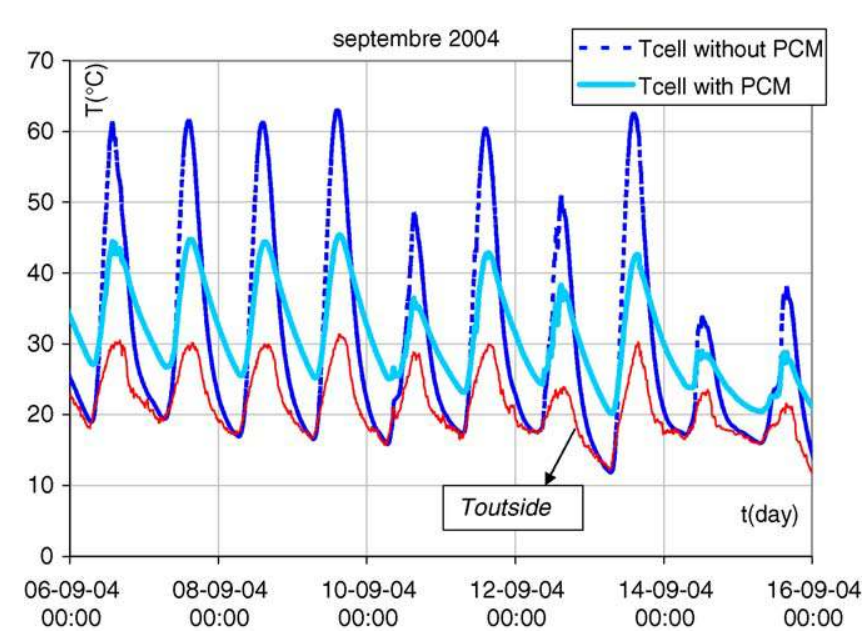

Fig. 9. Inside temperature of the two test-cells (without and with PCM) for September 2004.

glazing, overheats the interior atmosphere of the cells. If we carry out the energy balance of the cells during $24 \mathrm{~h}$ (4 November 2003), energy entering the cell corresponds to the solar radiation received by the glazed face, decreased by the transmission of the glazing estimated at $80 \%$. Energy entering the cell during 1 day is thus the integral of entering flow, i.e. $9015 \mathrm{~kJ}$. The energy stored in the wall is calculated by the following integral (surfaces between the curves of Figs. 8 and 9 and the axis):

$\int_{0}^{t}\left(\varphi_{\mathrm{e}}-\varphi_{\mathrm{i}}\right) A \mathrm{~d} t$

\subsection{Energy balance on the west panel without PCM}

Referring to Fig. 7 the heat balance on the west wall without PCM can be decomposed as:

energy stored by the panel due to the heating of the cell: $\int \varphi_{\mathrm{i}} \mathrm{d} t<0,184 \mathrm{~kJ}$

stored energy due to the external contributions: $\int \varphi_{\mathrm{e}} \mathrm{d} t>0$, $5 \mathrm{~kJ}$;

losses (or released energy) towards outside: $\int \varphi_{\mathrm{e}} \mathrm{d} t<0$, $186 \mathrm{~kJ}$;

losses (or released energy) towards inside: $\int \varphi_{\mathrm{i}} \mathrm{d} t>0,6 \mathrm{~kJ}$.

The total balance is established as follows: the energy transmitted to the wall is equal to $189 \mathrm{~kJ}$ and the energy transmitted by the wall is $192 \mathrm{~kJ}$. For this day and this orientation the gains and the losses on a wall are approximately balanced meaning that the wall transmits the same flux in both directions.

\subsection{Energy balance on the west panel with PCM}

It is observed in Fig. 8 that during the diurnal period the heat flux $\varphi_{\mathrm{i}}$ is negative and the heat flux $\varphi_{\mathrm{e}}$ is nearly zero in the morning and positive in the afternoon. During the nocturnal period the heat flux $\varphi_{\mathrm{i}}$ is positive and $\varphi_{\mathrm{e}}$ is slightly negative. 
Writing the heat balance as for the wall without PCM, we obtain

energy stored by the panel due to the sunning of the cell: $\int \varphi_{\mathrm{i}} \mathrm{d} t<0,956 \mathrm{~kJ}$

stored energy due to the external contributions: $\int \varphi_{\mathrm{e}} \mathrm{d} t>0$, $47 \mathrm{~kJ}$;

losses (or released energy) towards outside: $\int \varphi_{\mathrm{e}} \mathrm{d} t<0$, $186 \mathrm{~kJ}$;

losses (or released energy) towards inside: $\int \varphi_{\mathrm{i}} \mathrm{d} t>0$, $441 \mathrm{~kJ}$.

The total balance shows that the energy transmitted to the panel is $1003 \mathrm{~kJ}$ and the energy restored by the panel is $627 \mathrm{~kJ}$. It is noted that the wall has, for this day, stored an energy of $376 \mathrm{~kJ}$, which corresponds to approximately $13 \%$ of the quantity of PCM present in the wall.

\subsection{Total heat balance for the test-cells}

A total heat balance is carried out in measuring the fluxes on five walls and in estimating the fluxes through the window whose solar radiation transmission coefficient is assumed to be $80 \%$. The heat transfer by the frame is also evaluated. Taking the convective overall heat transfer coefficient for the glazing as $U_{\mathrm{g}}=2.7 \mathrm{~W} \mathrm{~m}^{-2} \mathrm{~K}^{-1}$ and for the framework $U_{\mathrm{f}}=1.5 \mathrm{~W} \mathrm{~m}^{-2}$ $\mathrm{K}^{-1}$, the heat flow rate can be calculated by:

$\dot{Q}=\left(U_{\mathrm{g}} A_{\mathrm{g}}+U_{\mathrm{f}} A_{\mathrm{f}}\right)\left(T_{\mathrm{i}}-T_{\mathrm{o}}\right)$

The glazing surface is $A_{\mathrm{g}}=0.64 \mathrm{~m}^{2}$ and the equivalent surface of the framework is $A_{\mathrm{f}}=1.31 \mathrm{~m}^{2}$.

The energies stored during the day by the cell walls without and with PCM were 1084 and $5144 \mathrm{~kJ}$, respectively. The released energies are 1223 and $3251 \mathrm{~kJ}$, respectively. During this day, the walls of the cell without PCM did not store a significant amount of energy contrary to the walls with PCM. In this latter case, stored energy is to be compared with the storage capacity of the cell which is $14,800 \mathrm{~kJ}$. The total stored energy represents $35 \%$ of the heat storage capacity.

\section{Durability tests}

The data recording began on 26 August 2003 and is currently continuing. A data base for more than 20 months has been constituted and certain periods can be compared. As an example, the temperatures for several days of September 2004 are presented in Fig. 9 and have to be compared to those of September 2003 (Fig. 11). It is noted that after 480 thermal cycles, the PCM continues to play its role of thermal absorber. The used PCM (PEG 600) was previously tested for 1000 thermal cycles and no deterioration was observed [15]. Moreover, the walls with PCM are efficient at cutting overheating during sunny days in hot as well as in cold periods. This has been verified in winter when the cloudy period is not too long and when solar radiation can heat the cell indoor.

\section{Numerical simulation and modelling}

\subsection{Numerical simulation}

The cells, located outside, are thus subjected to the climatic variations which will constitute the external boundary conditions for the numerical simulation. The thermal behaviour of the test-cells was simulated by using the TRNSYS 15 software with IISiBat [16]. TRNSYS is a "transient system simulation program". The climatic parameters are the boundary conditions and the targeted results are the indoor temperatures. The TRNSYS software simulates the behaviour (thermal, hydraulic, ...) of systems and has a modular structure. The systems are considered to be a set of components interconnected to provide a given task. The component description is put under a mathematical form to be included into a computer program in FORTRAN. Each component is called a "Type" and the Type 56 defining a building with several zones was chosen. This Type computes the interactions between two or several zones by solving a set of coupled differential equations. The building model is a non-geometric one in which one zone is defined by one node. At each node, a thermal balance is realized in affecting to this node a heat capacity representing the mass of air and of eventual objects (furniture for instance) in this zone. This energy balance is composed of three terms, the convective term, the radiative term and the term coupling the zone to the others. Once the balance established, the internal energy rate is written as:

$C_{i} \frac{\mathrm{d} T_{i}}{\mathrm{~d} t}=\dot{Q}_{i}$

where $C_{i}$ is the heat capacity of the $i$ zone, $\dot{Q}_{i}$ the sum of the heat flow rates at the $i$ node, which is a function of $T_{i}$ and of temperatures of the adjacent zones. A system of differential equations is obtained which are simultaneously solved by the software. The complexity of a zone description is simplified by the use of a pre-processor called PREBID which generates a file which describes the outputs as well as the inputs necessary to Type 56.

A general TRNSYS working environment which includes a connection program used to create TRNSYS input files, required IISiBat support files. IISiBat is an acronym of French words which means Intelligent Interface for the Simulation of Buildings and is a general simulation environment program which has been adapted to house the TRNSYS simulation software.

\subsection{Modelling the wallboard}

Amongst the components available in the TRNSYS software, many walls can be chosen with many material arrangements. However, no wall with PCMs was available and a new wall component was added to TRNSYS. This wall model was created by a team at the Helsinki University of Technology (HUT) in which the heat equation is solved in 3D for a PCM which has various states: solid, liquid or two-phase [17]. The wall consists of 729 points where there are 9 nodes in each direction. The convection, the radiation and conduction 


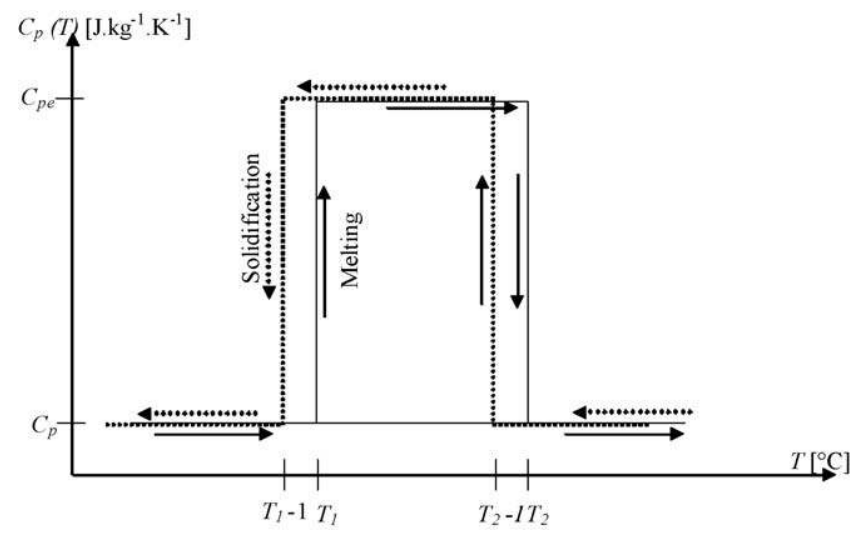

Fig. 10. Specific heat capacity as a function of temperature used in Type 101.

between the nodes are taken into account. The phase change is taken into account through a volume heat source leading to an equivalent specific heat capacity $C_{\mathrm{pe}}(T)$. It has been shown by Alisetti and Roy [18] that the shape of $C_{\mathrm{pe}}(T)$ has a weak influence on heat transfer. A rectangular shape was chosen by Lamberg and Piia [19] with a small supercooling of $1 \mathrm{~K}$ (Fig. 10). For a melting temperature range $\left[T_{1}, T_{2}\right]$, the equivalent specific heat capacity is given by

$C_{\mathrm{pe}}=\frac{L}{T_{2}-T_{1}}+\frac{C_{\mathrm{pS}}+C_{\mathrm{pL}}}{2}$

The variation of the specific heat capacity with temperature is:

$C_{p}(T)= \begin{cases}C_{\mathrm{ps}} ; & T<T_{1} \\ C_{\mathrm{pe}} ; & T_{1} \leq T<T_{2} \quad \text { when the temperature increases } \\ C_{\mathrm{pL}} ; & T \geq T_{2}\end{cases}$

and

$C_{p}(T)= \begin{cases}C_{\mathrm{pS}} ; & T<\left(T_{1}-1\right) \\ C_{\mathrm{pe}} ; & \left(T_{1}-1\right) \leq T<\left(T_{2}-1\right) \\ C_{\mathrm{pL}} ; & T \geq\left(T_{2}-1\right)\end{cases}$

when the temperature decreases

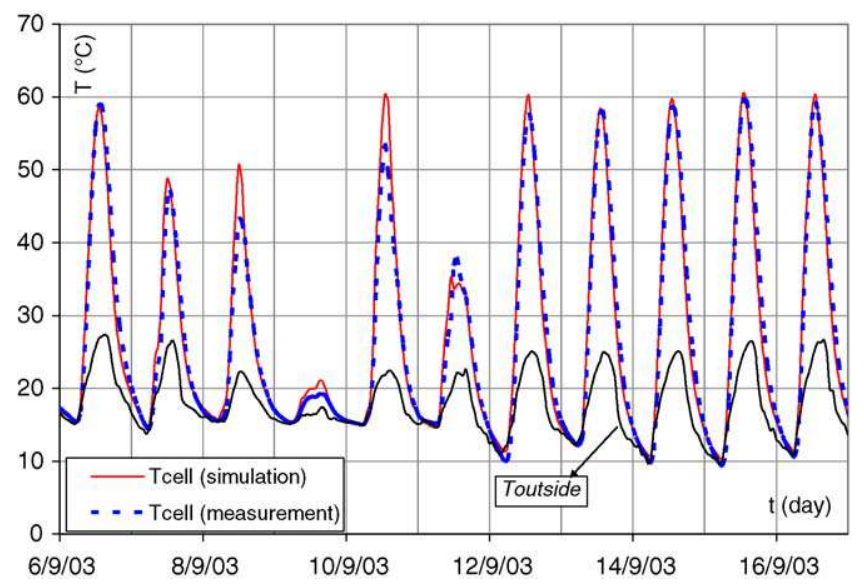

Fig. 11. Comparison of simulated and measured indoor temperatures of the test-cell without PCM during 10 days of September.

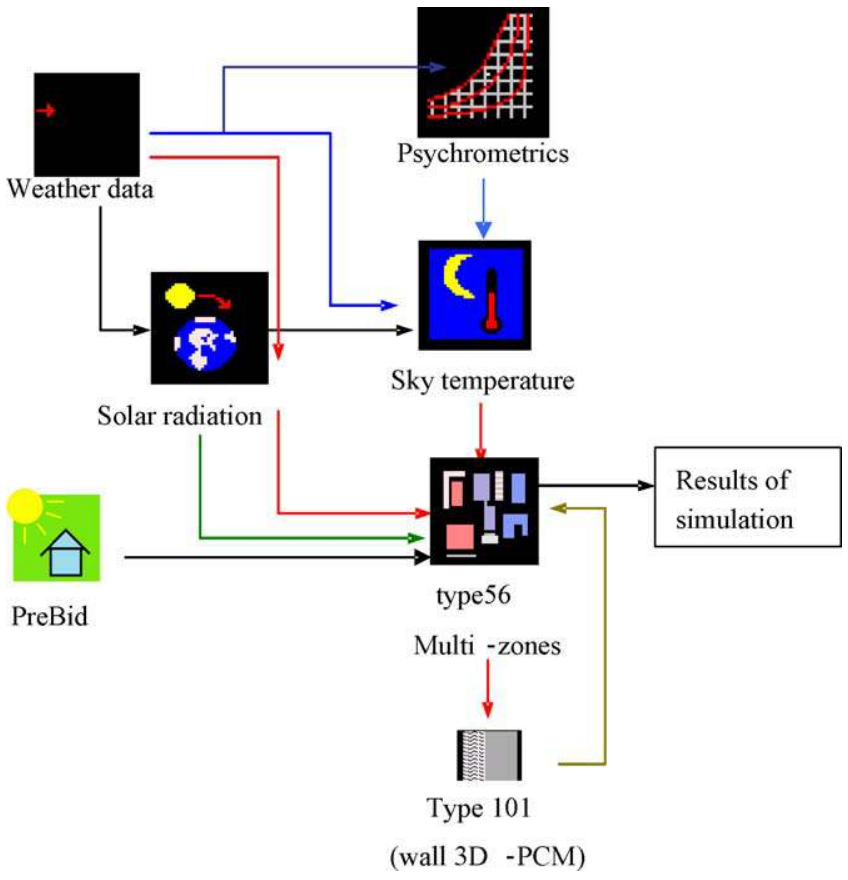

Fig. 12. Diagram for the PCM test-cell simulation showing the links between the different components under IISiBat interface.

The heat equation is then solved by a finite difference method with a Crank-Nicholson scheme and makes it possible to calculate the temperature at each node. We took this model and carried out some modifications to integrate it in TRNSYS which gave us a new Type that we called Type 101 [20]. Recently, a similar Type has been used to simulate the behaviour of buildings with walls containing PCMs [21].

\subsection{Cell without PCM}

Fig. 11 presents the indoor temperature variation given by the numerical simulation for several days of September 2003 compared with measurements for the same period. A good

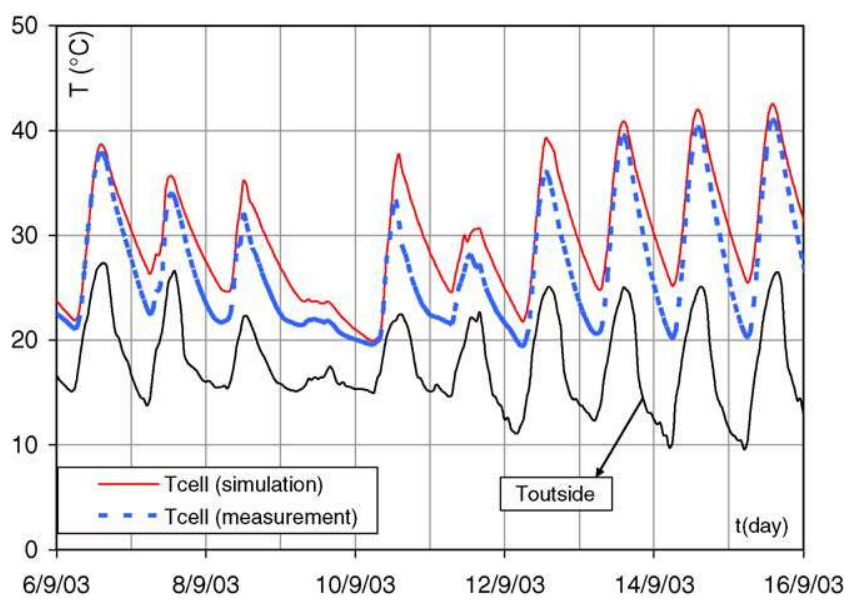

Fig. 13. Comparison of simulated and measured indoor temperatures of the test-cell with PCM during 10 days of September. 


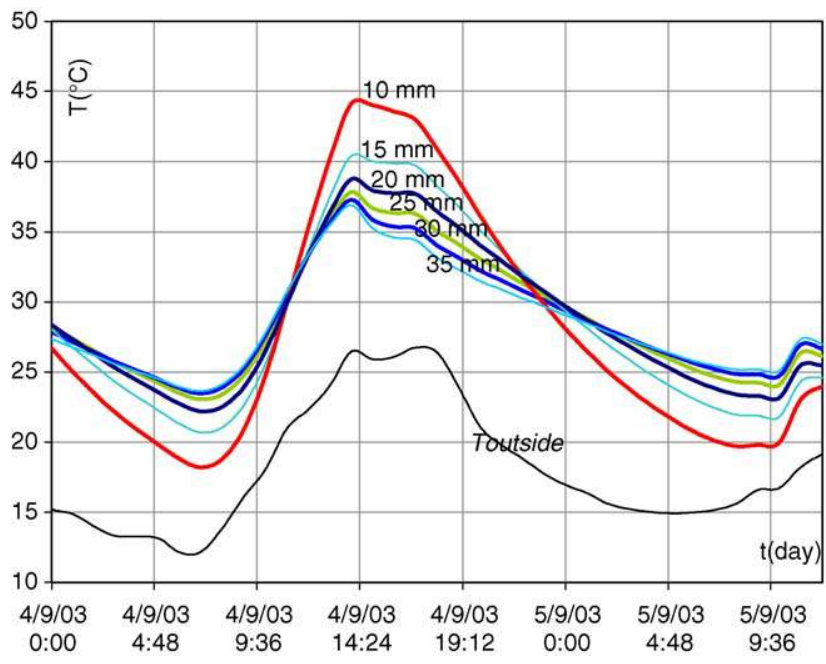

Fig. 14. Influence of wallboard thickness on the inside temperature of a test-cell with PCM for real climatic conditions.

agreement is found between simulation and measurements thus validating the model. The slight temporal shifting between measurements and simulation is probably due to a shift between the time base of the weather data and that of the measured temperatures. The absence of ventilation in the cells and the relatively large area of the glazed wall compared to the opaque walls explain the reached high level of the temperature.

\subsection{Cell with PCM}

The simulation of the test-cell with PCMs was made by including the Type 101 with some necessary modifications. Fig. 12 shows the diagram of the network as it appears on the computer screen, obtained to simulate the test-cell under the IISiBat environment. Type 56 describes the test-cell taking into account the walls with PCMs through the Type 101 .

Fig. 13 shows the simulation results for the same period as the cell without PCM. One notices a relatively good agreement between numerical simulation and experimental results. It is seen that, when the indoor temperature was high at the end of a diurnal period, the cell became cold slower in the simulation than in the real case. In the other hand, the amplitude of the temperature oscillations was generally smaller in the simulation than in the experiment. Several reasons can be invoked to explain these differences: (i) evaluation of the energy transmitted through the window, (ii) imprecision in the melting temperature range taken in the $C_{\text {pe }}$ definition, (iii) values of the convective heat transfer coefficient between wall surfaces and ambient air and (iv) existence of cold bridges. The influence of these different parameters has been evaluated and it appears that the introduction of cold bridges improved the simulation results. In adding a lineic resistance of $0.6 \mathrm{~m} \mathrm{~K} \mathrm{~h} \mathrm{~kJ}^{-1}$, the simulated temperature curve of the cell without PCM is practically not modified. In the contrary, the simulation curve of the cell with PCM tends to coincide with the experimental one.

\subsection{Parametric study: influence of thickness}

The influence of the wall thickness has been studied by numerical simulation. In Fig. 14 we present a comparison of the interior temperature of the cell test by giving different thicknesses of the walls with PCM. The numerical simulation shows that for a wall thickness more than $20 \mathrm{~mm}$ the temperature amplitude does not significantly decrease and the PCM is not efficient anymore. This value verifies the energy balance results.

\section{Conclusion}

The objective of this study is the realization of building components incorporating a phase change material coupled with a vacuum insulation panel (VIP) (i) to improve thermal inertia of the walls and comfort inside the buildings and (ii) to build a light envelope.

Two test-cells with super-insulated light wallboards were installed, one of them being equipped with PCM panels. Temperature and heat flux measurements allowed us to characterize the thermal behaviour of the two cells submitted to climatic conditions. A numerical simulation with the TRNSYS software has been carried out. This simulation required the implementation of a new computational module in the software. The use of this type of software has considerable advantages compared to application software. Indeed, with the help of the establishment of the new Type, any user is able to carry out a numerical simulation of a building having walls with PCM. An excellent agreement was found with the experimental results over a long period of time (several months) thus demonstrating the validity of the model. This study showed that the efficiency of PCM is remarkable with a reduction of the indoor temperature amplitude of approximately $20{ }^{\circ} \mathrm{C}$ in the test-cell. In summer the amplitude of the temperature inside the cell with PCM is decreased by $20{ }^{\circ} \mathrm{C}$ on a daily cycle. In winter, this prevents negative indoor temperature whilst the temperature of the cell without $\mathrm{PCM}$ is $-9{ }^{\circ} \mathrm{C}$ and that the outside temperature is below $-6{ }^{\circ} \mathrm{C}$. The PCM structure showed significant heat storage and release. PCM panels developed within the framework of this study seem interesting for future development.

The data recording began on 26 August 2003 and is currently continued. They thus cover about 20 months. It is noted that after more than 480 thermal cycles, the PCM continues to play its role of thermal absorber.

As the results showed that such a system can be constructed with commonly available materials and equipment, the optimization of the use of the solar contribution remains an essential element of the problems in the current context. Other PCMs are now under test to adapt the melting temperature to climatic conditions.

\section{Acknowledgments}

This work was partly financed by ADEME, Agence De l'Environnement et de la Maîtrise de l'Energie, French Agency for Environment and Energy Management. 


\section{References}

[1] G. Sarlos, A. Dauriat, Energy, a challenge for humanity in the 21st century, in: Proceedings of the International Conference on Energy and the Environment, Shanghai, China, December 11-23, 2003), pp. 1-5.

[2] Les chiffres clés du bâtiment, édition ADEME, 1999.

[3] M. Ahmad, A. Bontemps, P. Chambouleyron, H. Sallée, D. Quenard, Etude expérimentale de la réponse en température de cloisons contenant un matériau à changement de phase, Congrès Français de Thermique, SFT 2004, Presqu'île de Giens, May 25-28, 2004.

[4] S.M. Hasnain, Review on sustainable thermal energy storage technologies, Part I: heat storage materials and techniques, Energy Research 39 (11) (1997) 1127-1138

[5] B. Zalba, J.M. Marin, L.F. Cabeza, H. Melhing, Review on thermal energy storage with phase change materials, heat transfer analysis and applications, Applied Thermal Engineering 23 (2003) 251-283.

[6] K. Peippo, P. Kauranen, P.D. Lund, A multicomponent PCM wall optimized for solar heating, Energy and Buildings 17 (1991) 259-270.

[7] Z. Gu, H. Liu, Y. Li, Thermal energy recovery of air conditioning system-heat recovery system calculation and phase change materials development, Applied Thermal Engineering 24 (2004) 2511-2526.

[8] T. Kondo, T. Ibamoto, T. Yuuji, Research on thermal storage of PCM wallboard, Workshop for International Energy Agency, Annex 10, Japan, 2000

[9] J.K. Kissock, J.M. Hannig, T.I. Whitney, M.L. Drake, Early results from testing phase change wallboard, Phase Change Materials and Chemical Reactions for Thermal Energy Storage First Workshop, IEA Annex 10, April 16-17, 1998.

[10] S. Scalat, D. Banu, D. Hawes, J. Paris, F. Haghighata, D. Feldman, Full scale thermal testing of latent heat storage in wallboard, Solar Energy Materials and Solar Cells 44 (1996) 49-61.
[11] A.K. Athienitis, C. Liu, D. Banu, D. Feldman, Investigation of the thermal performance of a passive solar test-room with wall latent heat storage, Building and Environment 32 (1997) 405-410.

[12] Foam materials, http://www.basf.de.

[13] N. Kienzl, Advanced building skins, experimental evaluation of a prototypical translucent thermal storage element, in: Communication to ACSA 2001 Technology Conference, Austin, TX, USA, July 12-16, 2001.

[14] METEONORM, http://www.meteonotest.ch/.

[15] Cahier du centre scientifique et technique du bâtiment, livraison 244, November 1983, cahier 1892.

[16] TRNSYS, A Transient System Simulation Program, University of Wisconsin.

[17] J. Jokisalo, P. Lamberg, K. Sirén, Helsinki University of Technology, HVAC-Laboratory, Finland, piia.lamberg@hut.fi.

[18] E.L. Alisetti, K. Roy, Forced convection heat transfer to phase change material slurries in circular ducts, Journal of Thermophysics and Heat Transfer 14 (2000) 115-118.

[19] J. Jokisalo, P. Lamberg, K. Sirén, Suitability of Building Construction Materials in Short-term Energy Storage, Part 2, Thermal Simulation of Phase Change Materials in Concrete Products, Helsinki University of Technology, HVAC-laboratory, Report B64, 1999, 79 pp. (in Finnish).

[20] M. Ahmad, Nouveaux composants pour la gestion énergétique de l'enveloppe légère des bâtiments, Couplage Matériaux à Changement de Phase, Super isolation, Apports solaires, Ph.D. Thesis, Université Joseph Fourier, Grenoble, France, 2004.

[21] M. Ibáñez, A. Lázaro, B. Zalba, L.F. Cabeza, An approach to the simulation of PCMs in building applications using TRNSYS, Applied Thermal Engineering 25 (2005) 796-1807. 